\title{
Religion and Identity
}

\author{
Jeanne Brennan Kamat \\ Dallas University \\ Texas, USA \\ E-mail: jeannekamat@sbcglobal.net
}

\begin{abstract}
The complexity of human behavior has its beginnings in the influences of the earliest experiences of life, indeed in those in utero and especially in those of the youngest years of existence. How a person is accepted into life and begins the life journey is initially molded by parents and care givers. These essential relationships form personhood and those vital perceptions which will later determine choices. One inherits quietly, almost imperceptibly, the values of those who significantly touch one's life; and those values have been very much formed by the manner in which a person has followed, or not followed, the religious tenets that shape life events. The household of any specific religious understanding occasions for its members an atmosphere which animates the way of thinking, the way of speaking, and, in a sense, the entire manner of interacting. In context, the codes and precepts of a religion, or belief, determine the behavior of those who have chosen to live within its manner of perceiving the world and its people. This behavior is natural to them and shapes the experience of those with whom they interact. This paper examines the phenomenon of religion and identity through the insights of certain philosophers and psychologists, notably Martin Heidegger, Jacque Maritain, and John Cobb. It will also mention of Gabriel Marcel's analysis of the present situation of social interaction and the vision for the future of Teilhard de Chardin from his experience of life in the far East and its religions.
\end{abstract}

Keywords-identity; canon; conversion; convergence; intercommunication; mysticism; essential datum

\section{INTRODUCTION}

The present mode of world intercommunication has made all peoples aware of the diverse cultures and patterns of thought that exist on this one earth. Awareness is the beginning of interaction and it may take many forms. How one views differences with respect to one's own manner of life is an essential consideration as populations intermingle and individual people become a reality beyond a text book study. With each person, newness is not novelty but otherness that has permanence and commands attention. Thus, the challenge arises to truly know and believe in oneself as the ground for understanding personhood clothed in a different garment. Knowing oneself opens the door to what others have to give and begins a pattern of mutual examination which deepens truth.

Essential to the lives of persons are religion and culture. Therefore, an examination of the place of religion in the formation of persons and their view of the world is a starting point for determining the manner of our future togetherness.

\section{RELIGION AND IDENTITY}

The complexity of human behavior has its beginnings in the influences of the earliest experiences of life. How a person is accepted into life and how a person's life's journey is begun are essentially molded by parents and care givers. These initial relationships form personhood and those vital perceptions which will later determine choices. This understanding of human development is integral to the thought of the anthropologist Alfred I. Hallowell who contends that "the individual's self-image and his interpretation of his own experience cannot be divorced from the concept of self that is characteristic of his society" [1]. This concept is further affirmed by the social psychologist Ivana Markova who holds that "there is no independent self; the self has arisen out of a relationship between the individual and his or her social environment" [2]. The diverse influences that surround an individual are taken into account also by Susan Andersen, professor of psychology, who has this conviction, "religious factors hold a decisive sway over an individual as well as political stances. More mundane are the social, occupational, and familial roles" [3]. From these comments it is understood that from the earliest moments of life, persons are subject to impressions that mold who they are. They instinctively copy behaviors and internalize something of the actual personhood of the ones they imitate.

A rather early concept of person equates human identity to one's effects on the world. This understanding comes from a very primitive concept of person as "one who is seen by others." It follows that if one is seen, it is then imperative that there be something worth seeing. In this scenario, the development of identity is based on reaction to exterior characteristics. However, with the Renaissance there comes an awareness of how a person presents himself. Therefore, identity develops from respect for talent, social position, property holdings, political influence - all of which do not reflect self-examination as a foundation for personal selfrespect. In modern times, Descartes introduces the concept of the self as subject, that to which all is related and by which all is interpreted. The focus is now from within. Yet, in a different perspective, the self is also object. Ultimately, the question is "how does one know oneself?" 
All of the above positions have validity with respect to a person's knowledge of himself. However, there is a subtle element in human development that is always present and exerting influence. It is relationship. What one encounters, especially on a regular basis, becomes a part of one. The physical environment into which one is born has its impact on later stages of life when it is no longer present. It is so deeply imbued within that its recollection draws forth the persons and thoughts and experiences which existed within its bounds. One is touched implicitly by one's first physical surroundings. In a similar way, one inherits quietly, almost imperceptibly, the values of those who significantly touch one's life; and those values are very much founded on the manner in which a person has followed, or not followed, the religious tenets that shape life events. The household of any specific religious understanding occasions for its members an atmosphere which animates the way of thinking, the way of speaking, and, in a sense, the entire manner of interacting. In other words, the codes and precepts of a religion or belief determine the behavior of those who have chosen to live within its manner of perceiving the world and its people. This behavior is natural to them and determines the living experience of those with whom they interact. Values intrinsic to religious observance found the identity of persons, found the truth of their perception of themselves, of others, of human experiences, and of nature. Religion surrounds the individual with the transcendent, with some understanding of God. As Richard Gula points out "whether we experience God, how we experience God, and what beliefs we hold about God, will have a pervasive, though not exclusive, effect on the sort of person we are and what we do" [4].

Martin Heidegger sees identity as a characteristic of being. He explains identity as 'belonging together'. He states, "If the element of together in 'belonging together' is emphasized, we have the metaphysical concept of identity which orders the manifold into a unity mediated by synthesis. This unity forms a systematic totality of the world with God as Being, as the ground, as the first cause, and as the highest being" [5]. Identity, therefore, bespeaks the unity of a thing with itself so that it can perceive the identity of the other and acknowledge transcendence. In other words, man is conscious of his own being and is aware of his position with respect to other beings. Saint Thomas explains that "in spontaneous reflection, each of us knows that he exists, knows the singular existence of this subjectivity that perceives, suffers, loves, thinks...man grasps that he is a self... there is ecstasy in the substantial existence of the self and in the presence of the immensity of the divine self at one and the same time" [6].

Philosophy holds that the divine reality is beyond conceptual knowledge. It is a transcendent self, inscrutable in its being, its goodness, its liberty, and its glory. In recognition of this transcendence, intelligent selves owe to it obedience and adoration. In the understanding of Jacques Maritain, "to enter oneself with all one's baggage, that is, one's own existence and flesh and blood, into the vital relationship in which created subjectivity is brought face to face with this transcendent subjectivity and looks to it for salvation, is the business of religion" [7]. Man's consciousness of himself with respect to this reality, and with respect to others, demands that there be precepts that determine how interactions should proceed. Consciousness of himself means foremost that man have an image of himself, that man know himself. Abraham Heschel addresses the necessity to know who man is because "action and motivation are determined by the image of man one is committed to, the context one seeks to relate to" [8].

We turn again now to how this image is formed. The impact of religion has already been stated. For the most part, religion as practiced centers in the study and veneration of sacred texts which have been carefully formulated by measuring their meaning against other recorded ways of thought. Such writings are known as canon and a community understands itself through these writings which express its knowledge of God, the earth, and the way in which one is to relate within the community of worship and with respect to those outside it. From such texts values are derived which determine behavior and relationships. In essence, the writings selected as canon are considered by the community to be divinely inspired. Therefore, they are the core of holiness and wholeness to a people and are the basic principles of a religious community. In the light of this, one's self-identity is through one's religious convictions which are the foundation of the truth of one's life. If, however, in the passage of time, one comes to intuit a different perception of truth, one can no longer be an authentic part of that original community. Such a change in understanding constitutes conversion and necessitates affiliation with those of like conviction.

The question now persists, what is the relationship among the diverse religious groups and with those who do not belong to any specific religious organization? Heschel proposes that religion as an institution is not the ultimate end. The ultimate end is God who can be the God of causation and unity as explained by Heidegger or the God of personal interrelations as Heschel would espouse in his Jewish tradition. Heschel's insight into God as Father inspires man to justice and love embodied in the practice of mercy and humility. The liturgies, sacraments, and prayers of specific religious denominations serve to remind of these values and focus life towards these ends. However, the very nature of man in and of itself moves him to act in accord with such virtue when man is attentive to the basic goodness of being and sensitive to human need. In this understanding, all persons are involved in a positive course of life and individual religious commitment is a personal choice and means to support the arduous task of remaining faithful to righteousness and love. There is, though, a certain understanding that mutual commitment through regular assembly adds another dimension of meaning to the pursuit of goodness. Religious organizations which support their members and likewise contribute to the alleviation of world problems are a mainstay of the assistance needed in so many areas of the world. Involvement in such causes brings with it new knowledge, awareness, and experience not found in tourist travel, economic transactions, or study abroad, because there is something of self-sacrifice, of extending beyond oneself in the commitment to alleviate suffering. 
In his discourse on postmodernity, Paul Lakeland contends that "self-fulfillment consists in accepting one's place as an individual and the place of one's species in a much larger picture" [9]. Such understanding contrasts with a post-modern, self-centered society which makes it harder and harder to be human because it does not open itself to be wounded by the plight of vast portions of humanity. The problems endemic in present culture, as perceived by Jurgen Habermas, "stem from various sources: a vapid amorality, materialism, consumerism, social and political indifference, and traditional values not transformed to be inclusive of new and different people and circumstances" [10]. However, there is hope in the convergence of all the persons who see the wisdom of seeing beyond themselves, beyond the fear of newness, to partake in what is different and make it a part of oneself. This is the challenge for religions today in all the pluralism of their traditions. John Cobb makes this assessment of the present situation, "In order to have meaning amid the multifarious approaches to God and the human behavior derived from beliefs, a religious tradition must maintain the ability to be faithful to its own past and yet be enriched and even transformed in its interaction with other traditions" [11]. With this mindset amidst the pluralistic nature of the world, there will be respect for the particularity of each set of claims and a renewed trust that truth has a common ground in the sincere search for it.

Because religion, genuinely espoused, takes root in the heart of persons and guides their lives, religious discourse assumes a heightened relevance because new insights can engender new choices. Certain criteria of parlance can be useful in such dialogue so that exchange is authentic, meaningful, and enlightening with respect to how individuals live, find value in day to day existence, and view the future and their final destiny. Some points for the success of such parlance center in: the ability to acknowledge that what seems irreducible difference in a religious expression may, in some degree, be similar to one's own; the ability to comprehend the tenets of an unfamiliar religion without concern about personal incorporation; the ability to relate the communication of the other to one's own belief system and perception of reality for the sake of recognizing shared truth which assists in moving toward convergence and allows for a new and deeper participation in the ongoing demands of life; the ability to recast one's understanding of divine providence from a belief that God directs the immediate fortunes of individuals to a perception that God maintains the earth and the universe in their integrity and allocates the care of individuals to the consequences of their own actions and the actions of others upon them. In other words, humanity is responsible before God to act with compassion and empathy and substantive mutual care because the great gift of God in his providence to man is free will. Intelligence expressed in creative ability, free agency, and conscience to know the good, are the gifts of Providence so that persons can interact in an integral way and partake in the fruits of knowing that they have occasioned joy in their affirmation of life. The experience of joy, the spontaneous reaction to goodness, surpasses the suffering experienced in carrying out an empathetic response to the immense needs of persons so much occasioned by man's misuse of his freedom. So much the wrongs of the earth result from man's not recognizing the truth of his own nature, his innate goodness. Religion reminds man of who he is and what he can accomplish. Persons convinced of their tradition's account of reality have no need to be threatened by other accounts or to contest other religious persuasions. It is necessary to realize that one cannot be what one is not, but that one can be open to greater truth and to the courage it takes to move forward with it. Truth undergirds human relations and is the point of universal convergence.

As persons live the truth as they perceive it and set aside any semblance in their interactions with others, genuine interchange is accomplished. Martin Buber describes such interchange as "resultant from the desire to further in the other's soul the disposition towards what one has recognized in himself as right because what is truly right is also in the other and is opened out in the presence of the other meeting in existential communication" [12]. The dynamic glory of being a person is in this manner of relationship where each promotes the good of the other and nothing is imposed in self-promotion. There is a healing power in such interaction. Trust is involved in this and trust mainly emanates from the religious faith one has in God and in the basic goodness of creation. Whatever the motivation, persons engaged in knowing the other for the sake of mutual benefit and harmony reveal themselves as 'present' which means, in the words of Gabriel Marcel, "to be at the disposal of the other" [13]. Marcel further explains that the root cause of the malfunction between persons is "an incapability of presence because of, not only occupation with, but encumberment with oneself" [14].

Intercommunication, the ability to enter into honest dialogue, is the pathway into a common future. In one aspect of his vision of the world Teilhard de Chardin observes, "The contemporary world is coming to be centered upon the belief that humanity ultimately forms one community and that human rights and dignity pertain to all members of the human species" [15]. The community of persons of which Teilhard speaks is grounded in the religions of the world which address for all different people the universal need for an absolute, for a principle of order, and for an axis of movement. The differences of religious traditions find a new meaning when they encounter and contribute to each other in open discussion. Familiarity exposes the common elements that contribute to forward movement and the desire to build a future together for the good of humanity and the benefit of the earth. This is not a syncretism but a recognition that within differences, known and accepted, there is love and genuine co-operation in fulfilling needs, engaging in creative projects, and stepping beyond unfounded fears that stifle the human spirit. In this way differences assume a new meaning and do not obstruct convergence but rather affirm its necessity. Religions shared in their diversity act as a motivating force for the psyche and give spiritual energy because of the sincerity of the disparate believers.

With respect to religion, Teilhard attests that "one of the surest marks of the truth of religion is the extent to which it brings into action, that is, causes to rise up from sources deep 
within a certain maximum of energy and effort because action and sanctification go hand in hand, each supporting the other" [16]. In this understanding, religion is the foundation of the spiritually transforming evolutionary process of persons coming together in a convergence that builds the earth and fulfills what the prophets foretold that "all nations will be one and swords will be beaten into plowshares" [17]. In this sense, religion advances toward the spirit and opens the way for a new mysticism. Teilhard warns against the common mistake of "regarding the spiritual as an attenuation of the material, whereas it is in fact the material carried beyond itself" [18]. For Teilhard, at the heart of religion lies the phenomenon of mysticism. However, the mystic is now "the supreme realist, the one who will chart a new road into the realities of the world. The way of mysticism must be integrated with the many-sided aspects of social and practical life here and now. It must provide humankind with a viable spirituality to cope with the problems, responsibilities, and choices of the contemporary world, rather than invite individuals to an inward escape from them. Spirituality is concerned with our capacity for world-transforming action and decisive moral choices. This spirituality must combine a commitment to the rich diversity of the world and human experience with the ongoing search for absolute oneness, transcendence, and divine union" [19]. Religion as an essential datum, as an integral part of the human phenomenon, must lead to union through mutual acceptance and action that enhance life on all levels. In such pursuit of the common good, truth will have its own say in the revelation of the central importance of personhood and the bond of love that arises in working together for the benefit of all. The positive contribution of all religions furthers this spirit. Such is the true energy of allowing diverse beliefs to accomplish together what is of value to each. It is an energy that cannot be extinguished by adverse forces because its source is in the transcendence one knows through one's religious commitment. This uniting spiritual element propels forward and builds the future in oneness of purpose beyond the possibility of singular effort. This convergence is not a depersonalized absorption where individual identity is lost in the one, but a union where oneness is experienced through the uniqueness of one's own personhood laid at the disposal of all. Religion as the affirmation of personhood in a God who accepts all and affirms all of life is where identity is found and where persons can pursue the joy of knowing who they are.

The words of Teilhard submitted to the initial meeting of the French branch of the World Congress of Faiths in 1947 witness to the necessity for opening a new view on world religions so that their regional impact may be experienced beyond their borders and truth be acknowledged through international sharing of what has been foundationally meaningful in diverse lives. From the fruits of his presence in many Eastern countries and his devotion to evolutionary scientific research, Teilhard brought this to the attention of those first attendees, "There is a future for human beings and the world. The possibility of such a future depends now on the union of all individuals, races, and nations. Although conditioned by technical and social progress, this union can ultimately only be achieved through sharing a common vision. A supreme center of attraction (one's concept of transcendence) and personalization are required. Scientific thought and religious faith have to be in much closer contact; only then can a convergent vision emerge. Without the central insights of the great religious traditions, human efforts toward creating greater sympathy, understanding, and union cannot find their true focus" [20].

The vision of Teilhard brings together the gentleness of the expression of the East in its sensitivity to nature and its perception of the divine in all persons and the energy of the expression of the West in its eagerness to advance in scientific methods to fulfill the needs of humanity and promote the harmony that reflects the divine plan. In such convergence of the areas of the world is the hope of peace.

\section{CONCLUSION}

Religion is an essential element of the human psyche. It is the interior acknowledgment that there is something more than self. It is the awareness of a fullness of being beyond one's own that elicits a certain awe not just with what is out there in the yet unknown, but with what presents itself to one's perception right now as the mystery of nature, the mystery of the creative ability of persons, the mystery of relationships. Religion is the lesson in humility which reminds man to see himself correctly and to recognize the true gift in the other. In the tension of human and transcendent is the challenge to move forward in a common perspective of goodness and righteousness for all people. In this tension is the challenge to affirm life always, not in general, but in the particularity of the individual person who alone can say, I love.

\section{REFERENCES}

[1] Alfred I. Hallowell, Culture and Experience. Philadelphia: University of Pennsylvania Press, 1955, p. 76.

[2] Ivana Markova, "Knowledge of the Self through Interaction," in Self and Identity, eds. Keysia Yardley and Terry Hones. Chichester: John Wiley \& Sons, 1987, p. 65.

[3] Susan M. Andersen, "The Role of Cultural Assumptions in SelfConcept Development," in Self and Identity, eds. Krysia Yardley and Terry Hones. Chichester: John Wiley \& Sons, 1987, p. 231.

[4] Richard M. Gula, "Spirituality and Morality: What are We Talking About?" in Ethics and Spirituality. Mahwah, NJ: Paulist Press, 2014, p. 51.

[5] Martin Heidegger, Identity and Difference, trans. Joan Stanbaugh. Chicago: the University of Chicago Press, 1969, p. 12.

[6] Saint Thomas, "Self knowledge; the Soul's Knowledge of Itself" ST P. $1,87,1$.

[7] Jacques Maritain, Existence and Existent. Garden City: Doubleday Inc., 1957, p 80.

[8] Abraham Heschel, Who Is Man. New York: Bobbs-Merrill, 1953, p. 30.

[9] Paul Lakeland, Postmodernity: Christian Identity in a Fragmented Age. Minneapolis: Fortress Press, 1997, pp. 52.

[10] Jurgen Habermas, "Taking Aim at the Heart of the Present," in Critique and Power: Recasting the Foucault-Habermas Debate, ed. Michael Kelly. Cambridge: MIT Press, 1994, pp. 149-54.

[11] John Cobb, "Beyond Pluralism" in Christian Uniqueness Reconsidered: The Myth of a Pluralistic Theology of Religions. Maryknoll, NY: Orbis Books, 1990, p. 92. 
[12] Martin Buber, The Knowledge of Man. London: George Allen and Unwin, 1965, p. 82.

[13] Gabriel Marcel, "On the Ontological Mystery" in The Philosophy of Existentialism. New York: Philosophical Library, 1957. P. 38.

[14] Ibid., p. 43.

[15] Teilhard de Chardin, Spirtuality and Mysticism in an Evolutionary World in Teilhard de Chardin and Eastern Religions, ed. Ursula King. New York: Paulist Press, 2011, p. 153.

[16] Ursula King, Teilhard de Chardin and Eastern Religions. New York: Paulist Press, 2011, p. 185.

[17] Isaiah 2:4 The New American Bible. Nashville: Thomas Nelson Publishers, 1970, p. 779.

[18] Ursula King, p. 207

[19] Ibid.,p.229.

[20] Ibid., p.96. 